\title{
The Effect of Consumer Value on Attitude Toward Green Product and Green Consumer Behavior in Organic Food
}

\author{
Lucky Adhitiya $^{1}$ and Rifelly Dewi Astuti ${ }^{1}$
}

\begin{abstract}
At the moment the world market continues to change, sustainability pillars such as environment, economy and social justice have become part of marketing decisionmaking. Developing a marketing strategy in the midst of current environmental and economic issues has led to a focus on the importance of green marketing. Using the theory of consumption values and value-attitude-behavior model, this research proposes to explore the green consumer behavior for green products in Indonesia. Attitude toward green product and consumer values such as functional value (price and quality), social value, conditional value, epistemic value, emotional value, and environmental value were used to study the green consumer behavior for green products. This study developed a research model and empirically tested by collecting data from questionnaires that were distributed in Indonesia. Based on a sample of 200 respondents, the results indicate that only social value has a positive impact on green consumer behavior, functional value (price), functional value (quality), environmental value, conditional value, epistemic value, and emotional value do not influence green consumer behavior. As a mediator, attitude toward green product has a significant effect on epistemic value, environmental value, and emotional value. This confirms and significantly adds to the literature of green consumer behavior in a developing market.
\end{abstract}

Keywords-Green Products, Green Consumer Behavior, Value-Attitude-Behavior Model, Theory of Consumption Values.

\section{INTRODUCTION}

At the moment the world market continues to change, sustainability pillars such as environment, economy and social justice have become part of marketing decisionmaking. Developing a marketing strategy in the midst of current environmental and economic issues has led to a focus on the importance of green marketing [1][1]. Green marketing itself appears with large companies with international scale that have environmental sustainability and change, thus they are faced with the challenge of linking environmental issues into the company's strategies and business activities [2]. The goal of green marketing itself is to include environmental issues in marketing, where companies provide better information to consumers about the green properties of the products offered, this will

\footnotetext{
${ }^{1}$ Lucky Adhitiya and Rifelly Dewi Astuti are with Magister of Management, Universitas Indonesia, Jakarta, 10430. Email: luckyadhitiya16@gmai.com; rifelly.dewi@gmail.com.
}

increase the results of their purchases and will encourage companies to produce better products from the point of view of the Environment [3]. By developing movements to pay more attention to the environment, consumers will eventually change their buying behavior and it becomes easier to accept green products [4].

Green products have gained increasing attention in recent years due to the friendliness of their environment in the manufacturing process, emissions used are low, can be recycled, etc [5]. The development of environmentally friendly production and consumption has become a global trend. For sustainable earth development, we must try to change the habits of traditional production and consumption [4]. Based on European Commission (2014), three-quarters of people from European countries are even willing to pay more for environmentally friendly products [6].

Based on data obtained from Indonesian Organic Statistics, the total area of organic land in 2016 was 261.4 hectares (ha), while those already certified were 79.8 ha. The largest organic product from Indonesia is coffee, which is as much as 346,200 tons with a land area of 46,924 ha. Then rice which reaches a total production of 12,276 tons, followed by honey with a total production of 2,702 tons [7].

One example of a green product in Indonesia that is on the rise is organic food. This is proven by many buyers who are captivated by Indonesia's natural products during the COTECA 2016 exhibition which took place on September 7-9 in Hamburg, Germany. At the exhibition 100 tons of organic cocoa with Trinitario varieties originating from the Flores and Aceh regions were purchased by Koawach from Germany who is a producer of energized powdered chocolate drinks and will import and market them in Germany [8].

Currently the interest to use organic or natural agricultural products among the community has increased. This increase is based on the increasingly conscious and selective consumers of the health quality of agricultural products they consume. Now people are more fond of organic products than products that use organic ingredients for their consumption. Public health can be increased by consuming safe and nutritious foods produced from organic agricultural products. The implementation of organic farming activities will create a healthy and safe work 
environment for farmers. In addition, exposure to synthetic chemical pollution will no longer be accepted or felt by farmers during agricultural production [9].

Lifestyle changes that occur in Indonesia in the past 30 years are the cause of the increasing variety of diseases [10]. Poor diet and unbalanced nutritional intake and lack of time spent exercising and resting are the effects of the busy life experienced by the community. The lack of information and understanding of the importance of starting a healthy lifestyle is alleged to be the reason why "healthy" is still considered expensive and requires a great struggle to start. Increasing public interest in consuming organic products is directly proportional to the trend of healthy lifestyles that exist today, where many people begin to understand the negative effects of using inorganic ingredients. Since a few years ago, organic food has become a trend. Organic food is considered better because, one of them, is free of pesticides [11]. This is important in today's society who are experiencing a change in diet. Now, many people eat not only to look full, but also to think about health and environmental issues.

Consumer valuation of a product is not only based on quality and performance, but also takes into account the pleasure and pleasure that comes from the product (emotional value) itself and social pressure about what the product communicates to others (social value) [12]. In addition, there are several values that can influence consumer choice behavior, namely: emotional, epistemic, social, conditional, and functional values. These values do not depend on each other and contribute differently to various chosen situations [13].

Based on above study, this study aim to investigate the effect of consumer value on attitude toward green product and green consumer behavior in organic food. Consumer value in this study consist of functional value (price and quality), social value, conditional value, epistemic value, emotional value, and environmental value. The research was located in Indonesia, with respondents who know about green products such as organic food and people who can mention one of the green product examples in the organic food category. This research is expected to provide benefits as reference material for further research in an effort to determine the effect of consumer value on attitudes toward green products and green consumer behavior in organic food.

\section{METHOD}

\section{A. Value-attitude-behavior Model}

According to Homer \& Kahle (1988), in certain situations, the influence theoretically must flow from abstract values to intermediate attitudes then towards specific behaviors. This sequence can be called a hierarchy of values - attitudes - behaviors [14]. Thus, values are the underlying things that can explain a person's attitude and behavior. The attitude is conceptualized as a result that results from various factors including one's personal values. According to Shin, Moon, Jung, \& Severt (2017), attitudes are seen as less stable when compared to values [15]. According to Al Mamun, Mohamad, \& Yaacob (2018), attitudes are considered as one of the important factors that one can evaluate in terms of the benefits of purchasing environmentally friendly products. As a consequential result of values and attitudes, a person exhibits actual behavior [16].

\section{B. Green Product}

According to Fraccascia, Giannoccaro, \& Albino (2018), defining green products is a difficult task, because there are many different dimensions in which the term "green" is used such as: ecological, political, corporate social response, fair trade, conservation, new consumerism, and sustainability [17]. Therefore, there is no definition that is developed and used universally from a green product, but there are many different definitions developed by various parties: industry groups, trade unions, academics, and policy institutions [18].

Green product is defined by Commission of European Communities (2001) as a product that "uses less resources, has a lower impact and risk on the environment, and prevents waste piles already at the conception stage" [19]. Fraccascia, Giannoccaro, \& Albino (2018) realize that it is impossible to define environmentally friendly products in absolute conditions. Thus, a product can be considered "green" if it has a higher environmental performance than the traditional one at parity functions. This performance is not limited to the production phase but is extended to the overall product life cycle [17].

\section{Green Consumer Behavior}

Green consumer behavior refers to the purchase of products that are environmentally friendly or products that are sustainable (which can be recycled and benefit the environment) and avoid products that endanger the environment and society [20]. While according to Tan, Johnstone, \& Yang (2016), green consumption is a problematic concept because "green" implies conservation of natural resources while "consumption" generally involves the destruction of natural resources [21].

Consumer behavior in purchasing environmentally friendly products is generally evaluated in terms of their willingness to buy or the intention to buy environmentally friendly products and this will eventually turn into their purchasing decision for the product in maintaining environmental sustainability [20]. According to Wang, Huscroft, Hazen, \& Zhang (2018), consumer decision making can be motivated or based on information. Consumers decide what they will buy more based on information gathered and analyzed about a product [22].

According to Tan, Johnstone, \& Yang (2016), some situational factors such as constrained economics and lack of choice and availability can create obstacles for green consumer behavior (GCB). So even with factors such as 
perceived quality, lack of information and cynicism can also influence consumption decisions [21]. Consumer behavior is not only influenced by attitudinal factors, but also requires several other cognitive factors such as attention, knowledge, and effectiveness of consumers with direct attitude measures and / or to deal with consumer purchase intentions and their buying behavior towards common environmentally friendly products [20].

\section{Consumer Value}

According to Sweeney \& Soutar (2001), consumer valuation of a product is not only based on quality and performance, but also takes into account the pleasure and pleasure that comes from the product (emotional value) and social pressure about what the product communicates to other people (social value) [12]. According to Yeh, Wang, \& Yieh (2016), consumer value is the foundation of a successful transaction and it motivates consumers to buy repeatedly [23]. The consumption value theory was developed by Sheth, Newman, and Gross in 1991, they identified five consumer values that influence consumer choice behavior, namely: functional value, social value, emotional value, epistemic value, and conditional value [13].

\section{E. Functional Value}

Functional value measures consumer perceptions of a product based on price, quality, endurance, dependence, and reliability, that is, the value obtained from its benefits, functions, or physical performance. This is considered the main driver of consumer choice [24]. Functional value is divided into two dimensions - price and quality - by (Sweeney \& Soutar, 2001), which applies the PERVAL scale for the durability of goods. (Bei \& Simpson, 1995), shows that consumers evaluate prices and quality closely when deciding whether to buy recycled products [25]. Green product purchases are influenced by their functional value (price) [26]. Based on the explanation above, the hypothesis proposed is:

$H_{1 a}$ : Fuctional value (price) has a positive effect on green consumer behavior on green products.

$H_{1 b}$ : Fuctional value (quality) has a positive effect on green consumer behavior on green products.

\section{F. Social Value}

Social value measures the perceived usefulness of a product or service that is related to a particular social, demographic, socio-economic or cultural group [24]. This is related to self-image (Sweeney \& Soutar, 2001) that the extent to which a product is seen to improve self-image has a significant impact on green consumer behavior [26]. Based on the explanation above, the hypothesis proposed is:

$H_{1 c}$ : Social value has a positive effect on green consumer behavior on green products.

\section{G. Conditional Value}

Conditional value is perceived utility originating from a particular situation or set of conditions (Sheth, Newman, \& Gross, 1991) and arises when the use of a product or service is associated with certain circumstances [27]. Conditional value greatly influences green consumer behavior [28]. Changes in situation variables (certain conditions) can affect the purchase of green products [29]. Based on the explanation above, the hypothesis proposed is:

$H_{1 d}$ : Conditional value has a positive effect on green consumer behavior on green products.

\section{H. Epistemic Value}

Epistemic value is the utility that consumers feel comes from the ability of a product or service to arouse curiosity or provide novelty [24]. The desire of consumers to learn more about product attributes can affect the green consumer product purchase behavior [30]. Seeking newness also stems from the desire to know more, for example, to solve problems [28]. Based on the explanation above, the hypothesis proposed is:

\section{$\mathrm{H}_{1 \mathrm{e}}$ : Epistemic value has a positive effect on green} consumer behavior on green products.

\section{Environmental Value}

Environmental value measures consumer attitudes to environmental problems such as population increase, pollution, energy conservation, waste resources, and toxic effects of agents in the atmosphere and natural habitat [31]. Straughan \& Roberts (1999) found a positive correlation between environmental values and environmentally friendly behavior [32]. Based on the explanation above, the hypothesis proposed is :

Hif: Environmental value has a positive effect on green consumer behavior on green products.

\section{J. Emotional Value}

Emotional value measures perceived utility that associates consumers with the ability of a product or service to generate feelings or affective states [24]. Emotional response is influenced by benefits obtained by consumers of goods or services [12]. The rational and emotional factors related to the product or service play an important part in all purchasing decisions [33]. Emotional values were found to have a significant positive relationship with the green consumer purchase behavior product [28]. Based on the explanation above, the hypothesis proposed is :

$H_{1 g}$ : Emotional value has a positive effect on green consumer behavior on green products.

\section{K. Attitude Toward Green Product as a Mediating Value}

According to Ajzen (2005), attitude means evaluative assessment of an object, which consists of beliefs, perceptions and evaluation of results. This is the center of efforts to predict and explain behavior [34]. Prakash \& 
Pathak (2017) suggest that attitudes towards product packaging are one of the important fields that require attention so that they can build consumer trust in buying environmentally friendly products [35]. Suki (2014) also suggested the use of green product packaging with selfdeclarative claims to help consumers choose alternative green products [36]. Based on the explanation above, the hypothesis proposed is :

$\mathrm{H}_{2 \mathrm{a}}$ : Attitude toward green product mediates the influence of functional value (price) on green consumer behavior on green products.

$\mathrm{H}_{2 \mathrm{~b}}$ : Attitude toward green product mediates the influence of functional value (quality) on green consumer behavior on green products.

$\mathrm{H}_{2 \mathrm{c}}$ : Attitude toward green product mediates the influence of social value on green consumer behavior on green products.

$\mathrm{H}_{2 \mathrm{~d}}$ : Attitude toward green product mediates the influence of conditional value on green consumer behavior on green products.

$H_{2 e}$ : Attitude toward green product mediates the influence of epistemic value on green consumer behavior on green products.

H2r: Attitude toward green product mediates the influence of environmental value on green consumer behavior on green products.

$\mathrm{H}_{2 \mathrm{~g}}$ : Attitude toward green product mediates the influence of emotional value on green consumer behavior on green products.

\section{Methodology}

Figure 1 illustrates the study's research model, influenced by Theory of Consumption Values and Valueattitude-behavior Model. This study adopted from past research conducted by (Khan \& Mohsin, 2017), and adding variable attitude toward green product inspired by (Al Mamun, Mohamad, \& Yaacob, 2018).

\section{A. Data Collection and Sample}

Respondents in this study were people who knew about green products such as organic food and people who could mention one of the green product examples of organic food categories with age above 17 years because they were considered mature and had their own choices and perceptions. The sampling method in this study uses a nonprobability sampling method. Non-probability sampling method is a sampling technique that does not provide the same opportunity or opportunity for members of the selected population to be sampled [37]. The type of nonprobability sampling method in this study is snowball sampling. Snowball sampling is a sampling technique where respondents will refer researchers to others who have characteristics, experiences, or attitudes that are similar or different from their own [37]. This technique was chosen because it has advantages, namely the cost and time spent less.
The sample used in this study was 200 people in the Jabodetabek area. According to Malhotra (2010), the minimum number of samples that can be used for research is 200 people [37]. The questionnaire was written in Bahasa Indonesia and distributed online (using Google Docs, the link can be spread through social media, such as WhatsApp and Line).

\section{B. Measures and Analysis}

This research using questionnaire item adapted from previous studies. The variable items were measured using six-point Likert scale. The scale ranges from 1 ('strongly disagree') to 6 ('strongly agree'). The questionnaire items for functional value (price and quality), social, emotional, conditional, epistemic, environmental value, and green consumer behavior was adopted from Khan \& Mohsin (2017), and items for attitude toward green product was adopted from Al Mamun et al., (2018). Next, a path analysis are tested at significance values of t-values $>1.96$. Depending on the significance of the relationship, the value reflects the strength and direction of the relationship.

\section{RESUlT AND DISCUSSION}

\section{A. Measurement Analysis: Reliability and Validity}

Validity and reliability test using the Confirmatory Factor Analysis (CFA) method using AMOS software. The results obtained after using Confirmatory Factor Analysis (CFA) in the form of standardized factor loading values for each indicator variable, where the minimum value of the standardized factor loading is 0.50 [38]. After getting the standardized factor loading value from each indicator variable, the next thing to do is to calculate the Composite Reliability (CR) and Average Variance Extracted (AVE) values where both values determine whether each variable of this research is valid and reliable. According to (Malhotra, 2010), variables can be said to be valid and reliable if they have $C R$ value of $\geq 0.70$, and AVE value $\geq$ 0.50 [37].

In addition to getting the standardized factor loading, the suitability of a model will also be obtained where a model is said to be fit or good if it meets several criteria such as the value of Goodness of Fit Index (GFI) exceeds 0.90, the value of Tucker-Lewis Index or Non-Normed Fit Index (TLI or NNFI) exceeds 0.90, the Comparative Fit Index (CFI) value exceeds 0.90 , the value of the Root Mean Square Error of Approximation (RMSEA) is between 0.05 and 0.08 [39]. If the GFI value still shows a marginal fit, the steps that must be taken so that the GFI value shows good results is by respecification the indicators by considering the largest modification indices value of all indicators and also considering the smallest standardized factor loading of all indicators.

In respecifying the model and removing the indicators, one must do it one by one on each variable. The reason must be done gradually because if done simultaneously, the amount of respecification that must be done to achieve a 
good GFI value is unknown and the results of the standardized factor loading will be different.

Respecifications are carried out on several indicators such as, EpV3 with EpV4; ATE4 with ATE5; GCB3 with GCB4; GCB5 with GCB6; EnV1 with EnV3; FV_PR1 with FV_PR4; and GCB2 with GCB6. While some indicators were deleted because they have the smallest standardized factor loading values are indicators FV_PR4, CV4, EpV4, and GCB5. The following is the value of CR and AVE after specifying and deleting some indicators as shown in Table 1.

In addition to getting the standardized factor loading, $\mathrm{CR}$, and AVE values, the suitability of a model will also be obtained where in this study the GFI value obtained is 0.807 , the RMSEA value is 0.062 , the value of TLI is 0.911 , and the value of CFI is 0.923 . This shows that the model proposed in this research is quite good.

\section{B. Hypothesis Testing}

The hypothesis testing of the research was carried out using the help of AMOS 22 software. The results of the hypothesis testing were as shown in Figure 2. The summary results of the model hypothesis test as shown in Table 2.

Based on Table 2, it can be seen that from fourteen hypotheses proposed only four hypotheses which have tvalue values exceeding 1.96, namely the influence of social value on green consumer behavior with a t-value of 2.045, epistemic value influence on green consumer behavior by mediating attitude toward green product with a t-value of 3,331 , environmental value influence on the green consumer behavior by mediating attitude toward green product with a t-value of 4,656 and the effect of emotional value on the green consumer behavior with mediating attitude toward green product with a t-value of 4,816 .

\section{Discussion}

In this research the functional value (price), environmental value, and emotional value did not significantly influence the green consumer behavior, where the results were different from those obtained by Khan \& Mohsin (2017). But for functional value (quality), social value, conditional value, and epistemic value get the same results as in the research conducted by Khan \& Mohsin (2017) where functional value (quality), conditional value, and epistemic value have no effect significant to green consumer behavior, while social value has a positive and significant effect on green consumer behavior.

In addition, the functional value (price) and functional value (quality) variables get the same results as those obtained by Lin \& Huang (2012) but get different results for the conditional value variable where functional value (price), functional value (quality) and conditional value does not significantly influence the green consumer behavior [28]. Unlike the results obtained by Gonçalves, Lourenço, \& Silva (2016) where social value variables, epistemic value, environmental value, and emotional value positively and significantly influence green consumer behavior [40], in this research only social value variables have positive effect and significant effect on green consumer behavior while epistemic value variables, environmental values, and emotional values do not significantly influence the green consumer behavior.

According to (Bei \& Simpson, 1995), consumers tend to evaluate prices when they buy products that are environmentally friendly [25]. By not influencing the functional value (price) on green consumer behavior, it can be said that respondents did not evaluate the price when they bought a green product. This shows that prices are not a consideration for consumers to purchase green product in food categories. In addition, the majority of Indonesians already have expenditures above $\mathrm{Rp} 1$ million per month. This can be an indication that when they buy basic needs such as green product in food category they do not consider the price. In addition, the factor that consumers in Indonesia already have sufficient knowledge about green product in food category are much healthier than traditional products even though the price is slightly more expensive can be the reason why the functional value (price) does not affect the green consumer behavior.

According to (Bei \& Simpson, 1995) besides evaluating prices, consumers also evaluate quality when they buy products that are environmentally friendly [25]. Based on the results above, it shows that the quality of green products is not a consideration for consumers in buying green product in the food category. These results can be caused by the fact that consumers in Indonesia have sufficient knowledge about the green product in the food category so that when they buy organic food they are sure of the quality of the product and do not need to evaluate the product. In addition, the factor that respondents who filled out the questionnaire were respondents who had previously consumed green product in the food category, so they no longer needed to evaluate the quality of the green product.

According to (Sweeney \& Soutar, 2001) and (Finch, 2006), social values are often associated with one's selfimage where they will choose products that can improve their self-image [12], [26]. With the influence of social value on the green consumer behavior, it can be said that consumers in Indonesia choose and buy green products in the food category because they can improve the self-image of those who care about the environment in the eyes of others. In addition, by buying green product categories of foods that have slightly more expensive prices will improve the way they are seen in the community related to social status because they can afford products that are slightly more expensive than traditional products.

According to (Wang, Liao, \& Yang, 2013), conditional value arises when the use of a product or service is associated with certain conditions [27]. By not influencing conditional value towards green consumer behavior, it can be said that consumers in Indonesia do not need certain conditions to buy a green product. This shows that in 
buying a green product in the food category, consumers in Indonesia do not need a special condition such as a discount on a green product or if the green product is easy to obtain. Although in the absence of special conditions as previously explained, consumers in Indonesia will still buy the green product in the food category because it is one of the basic needs that they must fulfill.

According to [24], epistemic value is a benefit that consumers feel in the form of curiosity and novelty generated by a product or service. By not influencing epistemic value on green consumer behavior, it can be said that for consumers in Indonesia, especially respondents from this research feel that green products are not something new to them. Green products basically have no novelty compared to traditional products, the only difference being green products such as organic vegetables do not use pesticides or chemical fertilizers during the planting process. Based on this and because consumers in Indonesia have quite a lot of knowledge related to green products, they do not feel that there is something new offered by the green product and they feel that actually the green product is the same as traditional products, but the planting method is slightly different and it does not affect their buying behavior towards the green product in food category.

According to (Kim \& Choi, 2005), environmental value is a benchmark of consumer attitudes related to environmental problems [31]. Based on this, even though consumers in Indonesia already have considerable knowledge about green product food categories and already have experience in consuming green products but environmental values cannot encourage direct changes in consumers' green product purchasing behavior in Indonesia. This is because there are still many consumers in Indonesia who, although they already understand the environmental impact of the use of products that are not environmentally friendly but still survive in buying traditional products because they just understand they have not reached the stage where they have to really change the behavior of purchasing a green product.

According to [12], emotional responses are influenced by benefits obtained by consumers of goods or services. By not influencing direct emotional value on green consumer behavior, it can be said that for consumers in Indonesia, especially respondents from this research feel that the benefits they get from consuming a green product do not provide an emotional response. In other words, when consumers buy a green product in the food category they don't think of it as a right or good action because they have taken care of the environment but they buy because the green product in the food category is a basic necessity that they must fulfill. Therefore, when they buy a green product it does not touch their emotional side because it is just a fulfillment of their needs.

In this research, mediation analysis uses the Baron \& Kenny (1986) method, while the variables that can be mediated by the variable attitude toward green product are epistemic value, environmental values, and emotional value variables [41]. While other variables such as functional value (price), functional value (quality), social value, and conditional value cannot be mediated by the variable attitude toward green product.

This shows that prices are not a consideration for consumers to purchase green product food categories. In addition, even though consumers have a good attitude in buying a green product to influence their buying behavior, it cannot make consumers consider the price when making purchases on the green product food category. In addition, the factor that consumers in Indonesia already have enough knowledge about green product is a much healthier food category than traditional products even though prices are slightly more expensive and already have experience in consuming green products, making them not consider the price when buying a green product in food category.

In addition to price not being a consideration for consumers, it turns out that the quality factor of a green product is not a consideration for consumers in buying green product in the food category. These results can be caused by the fact that consumers in Indonesia have sufficient knowledge about the green product in the food category so that when they buy organic food they are sure of the quality of the product and do not need to evaluate the product. There is a factor that respondents who filled out the questionnaire were respondents who had previously consumed green product in the food category, so they no longer needed to evaluate the quality of the green product. In addition, even though consumers have a good attitude in buying green products to influence their buying behavior, this cannot make consumers evaluate the quality of the green product because they already have experience in consuming green products.

Consumers in Indonesia choose and buy green product food categories because they can improve self-image of those who care about the environment in the eyes of others so that it does not make them have a good attitude towards the green product. In addition, by buying green product categories of foods that have slightly more expensive prices will improve the way they are seen in the community related to social status because they can afford products that are slightly more expensive than traditional products.

Besides that consumers in Indonesia do not need a special condition such as a discount on green products and conditions if the green product is easy to obtain. Although in the absence of special conditions as previously explained, consumers in Indonesia will still buy the green product in the food category because it is one of the basic needs that they must fulfill. In addition, even though consumers have a good attitude in buying green products to influence their buying behavior, this does not make consumers look for a specific condition to buy a green product. 
Consumers in Indonesia feel that a green product is something new for them if they have a good attitude towards a green product. Green products have some novelty compared to traditional products, for example, as organic vegetables do not use pesticides or chemical fertilizers during the planting process. Based on this and because consumers in Indonesia have quite a lot of knowledge related to green products, they feel that green products actually have a novelty that is different from traditional products associated with a slightly different way of planting and that affects their buying behavior towards the green product in food category.

Besides that consumers in Indonesia already have enough knowledge about green product in food categories related to the minimum environmental impact produced by green products and already have experience in consuming green products and have a good attitude towards green products, this will result in green purchasing behavior consumer products in Indonesia. This is because there are quite a lot of consumers in Indonesia who already understand the environmental impact of using environmentally unfriendly products and begin to abandon traditional products that are still using pesticides and endanger the environment so that they can form consumer buying behavior towards green products.

Consumers in Indonesia feel that the benefits they get from consuming green products provide an emotional response when they already have a good attitude towards green products related to the minimum environmental impact produced by green products. In other words, when consumers buy a green product food category they will think of it as a right or good deed because they have helped preserve the environment when they have a good attitude towards the green product. Therefore, when they buy a green product it will touch their emotional side when they have a good attitude towards the green product.

\section{CONCLUSION}

Based on the results of the model processing and analysis that have been submitted, the conclusions that can be taken in this research, namely, variables that are able to directly influence the green consumer behavior are only social value variables with a t-value of 2,045. This explains that consumers in Indonesia, especially respondents in this research, chose the green product because they were able to improve the self-image of those who care about the environment. Meanwhile the variable attitude toward green product are able to mediate in full epistemic value, environmental value, and emotional value towards green consumer behavior. These results are based on mediation analysis using methods developed by (Baron \& Kenny, 1986). This explains that green consumer behavior will be formed after epistemic value, environmental value, and emotional value form the attitude toward green products first.

This study has limitations in the form of distributing questionnaires only in the Java island region, especially in big cities, where it is not able to represent the green consumer behavior in Indonesia. Suggestions that can be given for subsequent research related to green consumer behavior include the green product category is not limited to the food category only. In addition, further research can add several other variables related to green consumer behavior, with the hope that research results will become richer and provide an overview of the factors that can influence the green consumer behavior.

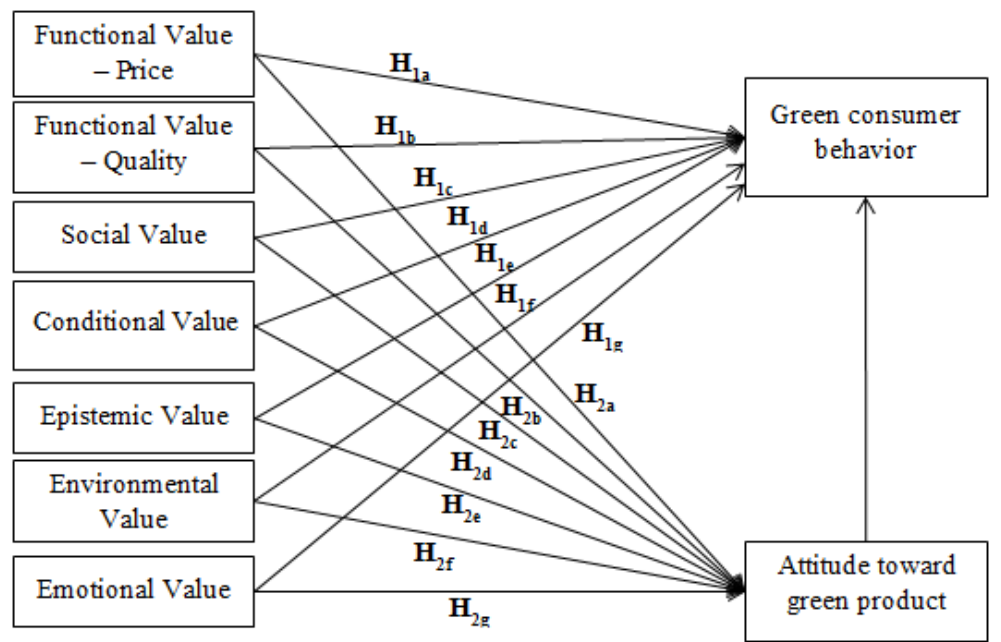

Figure 1. Research Model. 


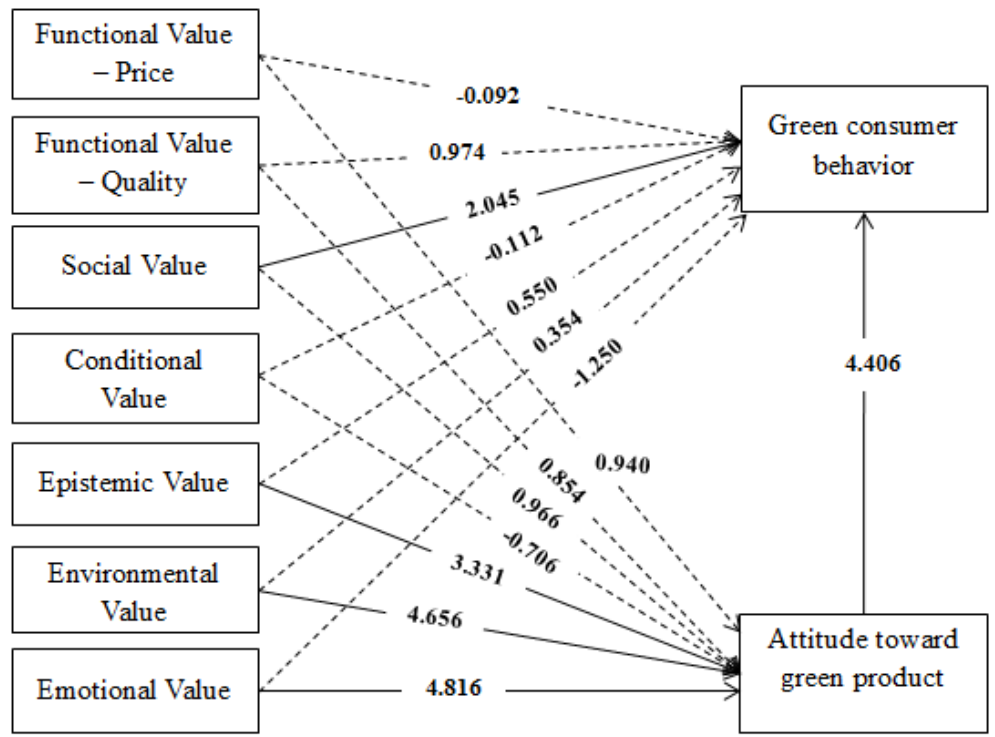

Figure 2. Result of Hypothesis Testing.

TABLE 1.

RELIABILITY AND VALIDITY

\begin{tabular}{|c|c|c|c|c|c|c|c|c|c|}
\hline Variable & Item & Factor Loading & Composite Reliability & AVE & Variable & Item & Factor Loading & Composite Reliability & AVE \\
\hline \multirow[t]{3}{*}{ FV_PR } & FV_PR1 & 0.779 & \multirow[t]{3}{*}{0.879} & \multirow[t]{3}{*}{0.708} & \multirow[t]{3}{*}{ EpV } & EpV1 & 0.912 & \multirow[t]{3}{*}{0.919} & \multirow[t]{3}{*}{0.79} \\
\hline & FV_PR2 & 0.858 & & & & EpV2 & 0.933 & & \\
\hline & FV_PR3 & 0.884 & & & & EpV3 & 0.818 & & \\
\hline \multirow[t]{4}{*}{ FV_Q } & FV_Q1 & 0.762 & \multirow[t]{4}{*}{0.884} & \multirow[t]{4}{*}{0.657} & \multirow[t]{4}{*}{$\mathrm{EnV}$} & EnV1 & 0.837 & \multirow[t]{4}{*}{0.919} & \multirow[t]{4}{*}{0.741} \\
\hline & FV_Q2 & 0.846 & & & & $\mathrm{EnV} 2$ & 0.786 & & \\
\hline & FV_Q3 & 0.814 & & & & EnV3 & 0.896 & & \\
\hline & FV_Q4 & 0.818 & & & & EnV4 & 0.918 & & \\
\hline \multirow[t]{4}{*}{ SV } & SV1 & 0.83 & \multirow[t]{4}{*}{0.904} & \multirow[t]{4}{*}{0.704} & \multirow[t]{5}{*}{ ATE } & ATE1 & 0.854 & \multirow[t]{5}{*}{0.89} & \multirow[t]{5}{*}{0.618} \\
\hline & SV2 & 0.917 & & & & ATE2 & 0.779 & & \\
\hline & SV3 & 0.719 & & & & ATE3 & 0.835 & & \\
\hline & SV4 & 0.876 & & & & ATE4 & 0.763 & & \\
\hline \multirow[t]{3}{*}{ EV } & EV1 & 0.89 & \multirow[t]{3}{*}{0.892} & \multirow[t]{3}{*}{0.734} & & ATE5 & 0.69 & & \\
\hline & EV2 & 0.885 & & & \multirow[t]{5}{*}{ GCB } & GCB1 & 0.695 & \multirow[t]{5}{*}{0.849} & \multirow[t]{5}{*}{0.532} \\
\hline & EV3 & 0.792 & & & & GCB2 & 0.89 & & \\
\hline \multirow[t]{3}{*}{$\mathrm{CV}$} & CV1 & 0.85 & \multirow[t]{3}{*}{0.822} & \multirow[t]{3}{*}{0.608} & & GCB3 & 0.7 & & \\
\hline & CV2 & 0.787 & & & & GCB4 & 0.708 & & \\
\hline & CV3 & 0.694 & & & & GCB6 & 0.629 & & \\
\hline
\end{tabular}

TABLE 2.

PATH ANALYSIS

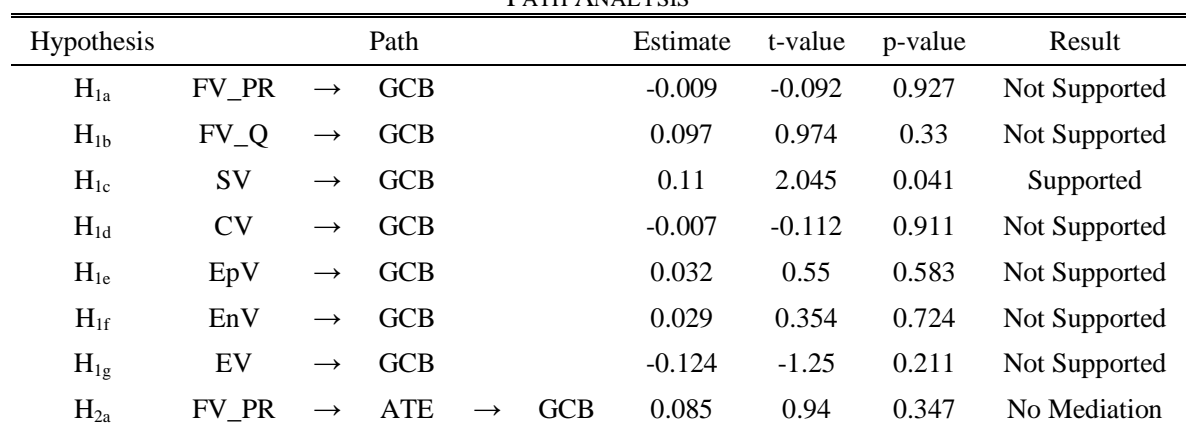


The $1^{\text {st }}$ International Conference on Business and Management of Technology (IConBMT)

August 3rd 2019, Institut Teknologi Sepuluh Nopember, Surabaya, Indonesia

\begin{tabular}{lcllllllll}
$\mathrm{H}_{2 \mathrm{~b}}$ & $\mathrm{FV} \_\mathrm{Q}$ & $\rightarrow$ & $\mathrm{ATE}$ & $\rightarrow$ & $\mathrm{GCB}$ & 0.076 & 0.854 & 0.393 & No Mediation \\
$\mathrm{H}_{2 \mathrm{c}}$ & $\mathrm{SV}$ & $\rightarrow$ & $\mathrm{ATE}$ & $\rightarrow$ & $\mathrm{GCB}$ & 0.047 & 0.966 & 0.334 & No Mediation \\
$\mathrm{H}_{2 \mathrm{~d}}$ & $\mathrm{CV}$ & $\rightarrow$ & $\mathrm{ATE}$ & $\rightarrow$ & $\mathrm{GCB}$ & -0.041 & -0.706 & 0.48 & No Mediation \\
$\mathrm{H}_{2 \mathrm{e}}$ & $\mathrm{EpV}$ & $\rightarrow$ & $\mathrm{ATE}$ & $\rightarrow$ & $\mathrm{GCB}$ & 0.168 & 3.331 & $* * *$ & Mediation \\
$\mathrm{H}_{2 \mathrm{f}}$ & $\mathrm{EnV}$ & $\rightarrow$ & $\mathrm{ATE}$ & $\rightarrow$ & $\mathrm{GCB}$ & 0.309 & 4.656 & $* * *$ & Mediation \\
$\mathrm{H}_{2 \mathrm{~g}}$ & $\mathrm{EV}$ & $\rightarrow$ & $\mathrm{ATE}$ & $\rightarrow$ & $\mathrm{GCB}$ & 0.383 & 4.816 & $* * *$ & Mediation \\
\hline \hline
\end{tabular}

\section{REFERENCES}

[1] R. G. Richey, C. F. Musgrove, S. T. Gillison, and C. B. Gabler, "The effects of environmental focus and program timing on green marketing performance and the moderating role of resource commitment," Ind. Mark. Manag., vol. 43, no. 7, pp. 1246-1257, Oct. 2014.

[2] R. M. Dangelico and D. Vocalelli, “'Green Marketing': An analysis of definitions, strategy steps, and tools through a systematic review of the literature," J. Clean. Prod., vol. 165, pp. 1263-1279, 2017.

[3] E. Rex and H. Baumann, "Beyond ecolabels: what green marketing can learn from conventional marketing," J. Clean. Prod., vol. 15, no. 6, pp. 567-576, 2007.

[4] Y. S. Chen, C. Y. Lin, and C. S. Weng, "The influence of environmental friendliness on green trust: The mediation effects of green satisfaction and green perceived quality," Sustain., vol. 7, no. 8, pp. 10135-10152, 2015.

[5] Z. Hong, H. Wang, and Y. Yu, "Green product pricing with non-green product reference," Transp. Res. Part E Logist. Transp. Rev., vol. 115, no. November 2017, pp. 1-15, 2018.

[6] TNS, Attitudes of European citizens towards the environment. Special Eurobarometer 416, no. May. 2014.

[7] M. N. Latief, "Indonesia Berpeluang Jadi Produsen Produk Organik Dunia," anadoluagency.com, 2018. [Online]. Available: https://www.aa.com.tr/id/ekonomi/indonesiaberpeluang-jadi-produsen-produk-organik-dunia/1093103.

[8] A. Budi, "Wuih, Produk Organik Indonesia Kebanjiran Order dari Jerman," 2016. [Online]. Available: https://www.goodnewsfromindonesia.id/2016/09/27/wuihproduk-organik-indonesia-kebanjiran-order-dari-jerman.

[9] Muh Iqbal Marsyaf, "Permintaan Produk Pertanian Organik Makin Meningkat," ekbis.sindonews.com, 2017. [Online]. Available:

https://ekbis.sindonews.com/read/1178984/34/permintaanproduk-pertanian-organik-makin-meningkat-1486784833.

[10] E. Pramita, "Jalani Pola Hidup Sehat dengan Manfaatkan Kekayaan Alam," Majalah Kartini, 2017. [Online]. Available: https://majalahkartini.co.id/berita/jalani-pola-hidup-sehatdengan-manfaatkan-kekayaan-alam/.

[11] A. W. Putri, "Rasa Superior di balik Makanan Organik," tirto.id, 2018. [Online]. Available: https://tirto.id/rasa-superiordi-balik-makanan-organik-cJQq.

[12] J. C. Sweeney and G. N. Soutar, "Consumer perceived value: The development of a multiple item scale," J. Retail., vol. 77, no. 2, pp. 203-220, 2001.

[13] S. N. Khan and M. Mohsin, "The power of emotional value: Exploring the effects of values on green product consumer choice behavior," J. Clean. Prod., vol. 150, pp. 65-74, 2017.

[14] P. M. Homer and L. R. Kahle, "Personality Processes And Individual Differences A Structural Equation Test Of The Value-Attitude-Behavior Hierarchy," J. Pers. Soc. Psychol., vol. 54, no. 4, pp. 638-646, 1988.

[15] Y. H. Shin, H. Moon, S. E. Jung, and K. Severt, "The effect of environmental values and attitudes on consumer willingness to pay more for organic menus: A value-attitude-behavior approach," J. Hosp. Tour. Manag., vol. 33, pp. 113-121, 2017.

[16] A. Al Mamun, M. R. Mohamad, M. R. Bin Yaacob, and M. Mohiuddin, "Intention and behavior towards green consumption among low-income households," J. Environ. Manage., vol. 227, no. August, pp. 73-86, 2018

[17] L. Fraccascia, I. Giannoccaro, and V. Albino, "Green product development: What does the country product space imply?," $J$. Clean. Prod., vol. 170, pp. 1076-1088, 2018.

[18] R. M. Dangelico and P. Pontrandolfo, "From green product definitions and classifications to the Green Option Matrix," $J$. Clean. Prod., vol. 18, no. 16-17, pp. 1608-1628, 2010.

[19] E. Commission, "Communication from the Commission to the Council on Telecommunications," Lines of Action, 1983.

[20] D. Jaiswal and R. Kant, "Green purchasing behaviour: A conceptual framework and empirical investigation of Indian consumers," J. Retail. Consum. Serv., vol. 41, no. November 2017, pp. 60-69, 2018.

[21] L. P. Tan, M. L. Johnstone, and L. Yang, "Barriers to green consumption behaviours: The roles of consumers' green perceptions," Australas. Mark. J., vol. 24, no. 4, pp. 288-299, 2016.

[22] Y. Wang, J. R. Huscroft, B. T. Hazen, and M. Zhang, "Green information, green certification and consumer perceptions of remanufctured automobile parts," Resour. Conserv. Recycl., vol. 128, pp. 187-196, 2018.

[23] C. H. Yeh, Y. S. Wang, and K. Yieh, "Predicting smartphone brand loyalty: Consumer value and consumer-brand identification perspectives," Int. J. Inf. Manage., vol. 36, no. 3, pp. 245-257, 2016.

[24] J. N. Sheth, B. I. Newman, and B. L. Gross, "Why we buy what we buy: A theory of consumption values," J. Bus. Res., pp. 159170, 1991.

[25] L.-T. Bei and E. M. Simpson, "The determinants of consumers' purchase decisions for recycled products: An application of acquisition-transaction utility theory," Adv. Consum. Res., pp. 257-261, 1995.

[26] J. E. Finch, "The impact of personal consumption values and beliefs on organic food purchase behavior," J. Food Prod. Mark., pp. 63-75, 2006.

[27] H.-Y. Wang, C. Liao, and L.-H. Yang, "What affects mobile application use? The roles of consumption values," Int. J. Mark., pp. 11-22, 2013.

[28] P. C. Lin and Y. H. Huang, "The influence factors on choice behavior regarding green products based on the theory of consumption values," J. Clean. Prod., vol. 22, no. 1, pp. 11-18, 2012.

[29] R. Saxena and P. K. Khandelwal, "Can green marketing be used as a tool for sustainable growth? A study performed on consumers in India - an emerging economy," Int. J. Environ. Cult. Econ. Soc. Sustain., pp. 277-291, 2010.

[30] C. Tanner and S. W. Kast, "Promoting sustainable consumption: Determinants of green purchases by Swiss consumers," Psychol. Mark., pp. 883-902, 2003.

[31] Y. Kim and S. M. Choi, "Antecedents of green purchase behavior: An examination of collectivism, environmental concern, and PCE. In G. Menon \& A. R. Rao (Eds.)," $A d v$. Consum. Res., pp. 592-599, 2005.

[32] R. D. Straughan and J. A. Roberts, "Environmental segmentation alternatives: A look at green consumer behavior in the new millennium," J. Consum. Mark., pp. 558-575, 1999.

[33] H. Mackay, Turning point: Australians choosing their future. Sydney: Pan Macmillan, 1999.

[34] I. Ajzen, Attitudes, Personality, and Behaviour. London: McGraw-Hill, 2005. 
[35] G. Prakash and P. Pathak, "Intention to buy eco-friendly packaged products among young consumers of India: A study on developing nation," J. Clean. Prod., pp. 385-393, 2017.

[36] N. M. Suki, "Investigating the Measurement of Consumer Ecological Behaviour, Environmental Knowledge, Healthy Food, and Healthy Way of Life," Int. J. Soc. Ecol. Sustain. Dev., pp. 12-21, 2014.

[37] N. K. Malhotra, Marketing Research: An Applied Orientation, 6th ed. Upper Saddle River, NJ: Pearson/Prentice Hall, 2010.

[38] J. F. Hair, W. C. Black, B. J. Babin, R. E. Anderson, and R. L. Tatham, Multivariate Data Analysis, 7th Editio. 2015.
[39] S. H. Wijanto, Metode Penelitian menggunakan Structural Equation Modeling dengan LISREL 9. Jakarta: Lembaga Penerbit Fakultas Ekonomi UI, 2015.

[40] H. M. Gonçalves, T. F. Lourenço, and G. M. Silva, "Green buying behavior and the theory of consumption values: A fuzzyset approach," J. Bus. Res., vol. 69, no. 4, pp. 1484-1491, 2016.

[41] R. Baron and D. Kenny, "The moderator-mediator variable distinction in social ...," J. Pers. Soc. Psychol., vol. 51, no. 6, pp. 1173-1182, 1986. 